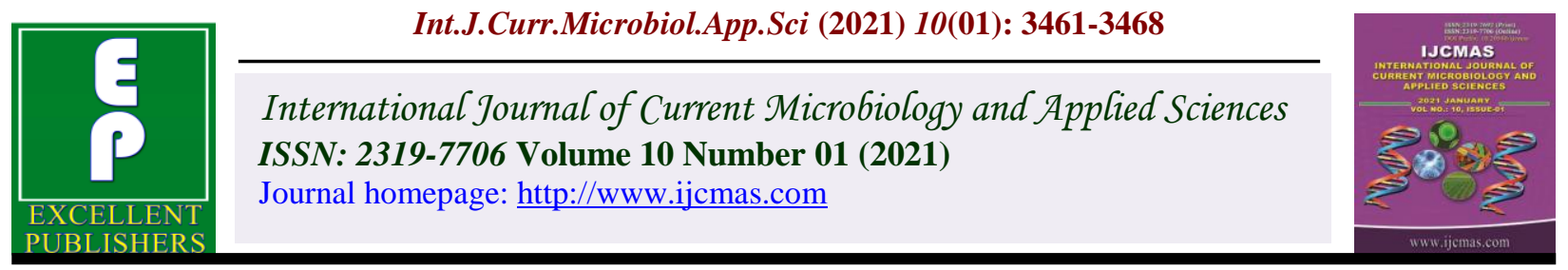

Original Research Article

https://doi.org/10.20546/ijcmas.2021.1001.408

\title{
Effect of Integrated Nutrient Management on Growth, Flowering and Yield of Gaillardia
}

\author{
Arti Arha*, R. A. Kaushik, S. S. Lakhawat, H. L.Bairwa and Arvind Verma \\ Department of Horticulture, Rajasthan College of Agriculture, Maharana Pratap University \\ of Agriculture and Technology, Udaipur \\ *Corresponding author
}

\section{A B S T R A C T}

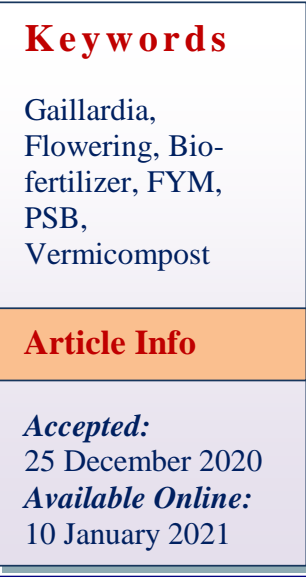

\section{Introduction}

Gaillardia is an ornamental plant and belongs to family 'Asteraceae', and native place of this flower is central and western United States. There are 30 species, out of which G.pulchella, G.aristata and G.grandiflora are of ornamental importance, being available in annual and perennial forms, respectively. Gaillardia pulchella, also known by the name as blanket flowers, among one of the hardiest annuals and is grown under different types of soils and varied climatic conditions.

Gaillardia is grown as an important Presently this crop has less area under commercial flower crop in different parts of India. Apart from religious purposes as loose flowers, these are also used for interior decoration viz., vases and bouquets. Despite its utility for landscape, gaillardia is also useful in reduction of erosion in coastal areas (Carig, 4). Gaillardia flourishes well in any kind of garden soil and it can also tolerate high level of light intensities, drought as well as high temperature in a better way as compared to most of the flowering plants. Up to a certain extent it can also tolerant to salinity (Tija and Rose, 18). 
cultivation; however, in the near future it is about to increase as flowers of gaillardia are in heavy demand now a days. In tropical climate, gaillardia can be grown throughout the year, but it is a major summer annual. It is also frost hardy. In gaillardia cultivation among all other important factors that can affect its performance, one is the nutritional management of the crop. The quality of flowers is highly influenced by the quantity of nutrients which are applied and the sources of these nutrients. Integrated nutrient management is a strategy for efficient and judicious use of chemical fertilizers with the addition of organic fertilizers and biofertilizers. The practice of using organic manures in conjunction with chemical fertilizers not only enhances the efficiency of fertilizers but also partly supply nutrients, at the same time improves the physical, chemical and biological properties of the soil. Such practices reduce the amount of inorganic fertilizers, control pollution in part at least the one caused due to use of high doses of fertilizers and also protects natural resources. Therefore, now the emphasis is on the utilization of organic manures like farm yard manure (FYM), vermicompost and biofertilizers like Azotobactor and phosphate solubilising bacteria (PSB).

Keeping in view the importance and need of research work on response of gaillardia to different combinations of nutrient treatments, the experiment, named "Integrated Nutrient Management in Gaillardia" was carried out.

\section{Materials and Methods}

This experiment was conducted to assess the effect of integrated nutrient management on gaillardia with respect to growth, flowering and yield parameters at Horticulture farm, Rajasthan College of Agriculture, MPUAT, Udaipur for two years during 2018-19 and 2019-20. This location situated at $24^{0} 35^{\prime} \mathrm{N}$ latitude and $24^{\circ} 42^{\prime} \mathrm{E}$ longitudes at an altitude of 579.5 meters above mean sea level. This region is under the agro climatic Zone IV A (Sub- humid Southern Plain and Aravali Hills) of Rajasthan. The experimental plot was uniform, leveled and had good drainage facility. The texture of soil was clay loam, with Soil $\mathrm{P}^{\mathrm{H}}$ 7.98, Soil EC $0.46 \mathrm{dsm}^{-1}$, available $\mathrm{N}$ in soil $185.6 \mathrm{~kg} \mathrm{ha}^{-1}$, available $\mathrm{P}_{2} \mathrm{O}_{5}$ in soil $26.4 \mathrm{~kg} \mathrm{ha}^{-1}$ available $\mathrm{K}_{2} \mathrm{O}$ in soil $251.4 \mathrm{~kg} \mathrm{ha}^{-1}$.

The experiment was laid out in randomized block design, which comprised 13 treatment combinations consisting of inorganic fertilizers (142:89:130 kg NPK), FYM, Vermicompost, Neem cake and bio-fertilizers (Azotobacter and PSB). The treatments consisted of $\mathrm{T}_{1}$, NPK (RDF) (142:89:130 $\mathrm{Kg} / \mathrm{ha}$ ) through inorganic fertilizers (Control), $\mathrm{T}_{2}$, FYM (50\% RDN) +Vermicompost (25\% $\mathrm{RDN})+$ Neemcake (25\% RDN), $\mathrm{T}_{3}, \mathrm{FYM}$ $(60 \% \mathrm{RDN})+40 \%$ recommended dose of NPK, $\mathrm{T}_{4}, \mathrm{FYM}(40 \% \mathrm{RDN})+60 \%$ recommended dose of NPK, $\mathrm{T}_{5}$, Vermicompost $(60 \% \mathrm{RDN})+40 \%$ recommended dose of NPK, $\mathrm{T}_{6}$, Vermicompost (40\% RDN) + $60 \%$ recommended dose of NPK, $\mathrm{T}_{7}$, Neem cake $(60 \% \mathrm{RDN})+40 \%$ recommended dose of NPK, $\mathrm{T}_{8}$, Neemcake (40\% RDN) $+60 \%$ recommended dose of NPK, T9 FYM $(30 \%$ RDN) + Vermicompost (30\% RDN) + 40\% recommended dose of NPK, T 10 , FYM $(20 \%$ RDN) +Vermicompost (20\% RDN) + 60\% recommended dose of NPK, $\mathrm{T}_{11}$, Vermicompost $(30 \% \mathrm{RDN})+$ Neemcake $(30 \% \mathrm{RDN})+40 \%$ recommended dose of NPK, $\mathrm{T}_{12}$,Vermicompost $(20 \%$ RDN $)+$ Neemcake $(20 \%$ RDN) $+60 \%$ recommended dose of NPK, T13, FYM (20\% RDN) + Vermicompost (20\% RDN) + Neemcake $(20 \% \mathrm{RDN})+40 \%$ recommended dose of NPK with Azotobacter and PSB. All treatments were replicated thrice. Plants were planted at $45 \mathrm{~cm} \mathrm{x} 45 \mathrm{~cm}$. There were 6 plants 
per row and total 5 rows making 30 plants in each plot of $2.25 \mathrm{~m} \mathrm{X} 2.7 \mathrm{~m}$.

A liquid bio-fertilizer mix (Azotobacter mixed with PSB) was obtained from the Department of MBBT, Rajasthan College of Agriculture Udaipur. Fertilizers like Nitrogen, Phosphorus and potassium in suitable sources were applied in the form of Urea, Single Super Phosphate (SSP) and Muriate of Potash (MOP) respectively. The dose of NPK through FYM, vermicompost and neem cake was incorporated as basal dose before transplanting of gaillardia as per treatments to the respective plots.

Calculation of Azotobacter $\left(4.5 \times 10^{9} \mathrm{cfu} / \mathrm{ml}\right)$ and PSB (50 x $\left.10^{10} \mathrm{cfu} / \mathrm{ml}\right)$ was done as per given treatment and these were thoroughly mixed with organic manure and then applied in their respective plots. As far as chemical fertilizers are concerned one-third dose of nitrogen and full dose of phosphorus and potash were supplemented as basal dose right before sowing of gaillardia. The rest of two third dose of nitrogen was supplied as top dressing at 30 days after sowing of the gaillardia crop.

The observations were recorded from randomly selected and tagged five plants at proper stage and statistically analyzed for different growth, flowering and yield parameters like plant height, spread of plant, days to initiation of first flower bud, number of days to opening of flower, number of days to $50 \%$ flowering, weight of flower, diameter of flower and flower yield plant ${ }^{-1}$.

\section{Results and Discussion}

Different nutritional treatments had significant effect on various growth parameters viz., plant height and spread of plant in gaillardia during both the years i.e. 2018-19, 2019-20 and in pooled analysis
(Table 1).

Significantly maximum growth with respect to plant height $80.96,83.96$ and $82.47 \mathrm{~cm}$ and plant spread N-S 85.88, 86.07 and $85.97 \mathrm{~cm}$ and E-W 81.80, 81.98 and $81.89 \mathrm{~cm}$, was recorded at full bloom stage in both the years and in pooled data with the application of treatment of FYM $(20 \%$ RDN $)+$ Vermicompost $(20 \%$ RDN $)+$ Neemcake $(20 \%$ RDN) $+40 \%$ recommended dose of NPK with Azotobacter and PSB $\left(\mathrm{T}_{13}\right)$. The better plant growth observed for above parameters in treatment $\mathrm{T}_{13}$ in the present investigation is because of the beneficial effect of neem cake, FYM, vermicompost, bio-fertilizers and chemical fertilizers. Organic manures with $40 \% \mathrm{RDF}$ might have led to enhanced availability of nutrients at vital periods of growth, greater synthesis and translocation of carbohydrates, improved water status of plants and increased nitrate reductase activity. The similar results were obtained by Thumar et al., (17) and Singh et al., (15) in marigold, Patanwar et al., (11) in chrysanthemum and Patil et al., (12) and Patil and Agasimani (13) in China aster.

FYM and vermicompost have many outstanding physico-chemical and biological properties. The micro flora and enzymatic activity has enhanced with the application of organic manures which might have augmented the plant growth. Nitrogen is fixed by Azotobacter and nitrogen (a constituent of protein) and chlorophyll plays a vital role in photosynthesis and also accelerates the process of cell division and differentiation. Azotobacter synthesizes as well as secretes growth substances like, riboflavin, thiamin, nicotinic acid, IAA and gibberellins. Production of antifungal antibiotics by them inhibits the growth of fungi those which are harmful and it has some other beneficial effect on plant growth. Azotobacter and PSB also releases growth regulators like cytokinins 
and NAA which results in breaking of apical dominance. PSB also enhances availability of phosphorous and promote root growth and lead to accumulation of carbohydrates which in turn, increased the growth of plant in gaillardia. These results are in close conformity with the findings of Rathod et al., (14), Karetha (6), Deshmukh et al., (5) and Sowmyamala et al., (16), in gaillardia.

Data pertaining to flowering parameters viz., days to initiation of first flower bud, number of days to opening of flower and number of days to $50 \%$ flowering were influenced by different nutritional treatments (Table 2).
It was found that organic fertilizers, inorganic fertilizers and their combined use through treatment $T_{13}$ minimized the days required for initiation of first flower bud, number of days to opening of flower and number of days to $50 \%$ flowering to a significant level. Minimum days for first flower bud initiation $44.15,42.93$ and 43.54 days, days to opening of flower 56.16, 54.94 and 55.55 days and days to $50 \%$ flowering $72.05,67.05$ and 69.55 days were recorded with treatment FYM $(20 \% \mathrm{RDN})+$ Vermicompost (20\% RDN) + Neemcake $(20 \%$ RDN) $+40 \%$ recommended dose of NPK with Azotobacter and PSB $\left(\mathrm{T}_{13}\right)$ in individual years and pooled analysis.

Table.1 Effect of integrated nutrient management on growth parameters of gaillardia

\begin{tabular}{|c|c|c|c|c|c|c|c|c|c|}
\hline \multirow[b]{2}{*}{ Treatments } & \multicolumn{3}{|c|}{ Plant height $(\mathbf{c m})$} & \multicolumn{3}{|c|}{ Plant spread N-S(cm) } & \multicolumn{3}{|c|}{ Plant spread E-W(cm) } \\
\hline & 2018-19 & 2019-20 & Pooled & 2018-19 & 2019-20 & Pooled & 2018-19 & 2019-20 & Pooled \\
\hline$T_{1} \operatorname{RDF}(142: 89: 130)$ & 80.96 & 83.96 & 82.46 & 82.16 & 82.37 & 82.26 & 76.75 & 76.91 & 76.83 \\
\hline $\begin{array}{l}\mathrm{T}_{2} \text { FYM }(20 \% \text { RDN })+\mathrm{VC}(25 \% \\
\text { RDN)+NC (25\% RDN)+ Azo+PSB }\end{array}$ & 65.36 & 68.33 & 66.84 & 67.47 & 67.68 & 67.57 & 60.95 & 61.13 & 61.04 \\
\hline $\begin{array}{l}\mathrm{T}_{3} \text { FYM( }(60 \% \\
\text { RDN)+40\% RDF+Azo+PSB }\end{array}$ & 66.45 & 69.45 & 67.95 & 74.17 & 74.38 & 74.27 & 67.74 & 67.92 & 67.83 \\
\hline $\begin{array}{l}\mathrm{T}_{4} \text { FYM }(40 \% \\
\text { RDN }+60 \% \text { RDF+Azo+PSB }\end{array}$ & 68.41 & 71.64 & 70.02 & 70.87 & 71.09 & 70.98 & 64.36 & 64.54 & 64.45 \\
\hline $\begin{array}{l}T_{5} \text { VC }(60 \% \\
\text { RDN)+40\% RDF+Azo+PSB }\end{array}$ & 72.25 & 76.58 & 74.41 & 75.99 & 76.17 & 76.08 & 69.97 & 70.15 & 70.06 \\
\hline $\begin{array}{l}T_{6} \text { VC }(40 \% \\
\text { RDN }+60 \% \text { RDF+Azo+PSB }\end{array}$ & 71.76 & 74.93 & 73.34 & 74.55 & 74.74 & 74.64 & 68.51 & 68.69 & 68.6 \\
\hline $\begin{array}{l}\mathrm{T}_{7} \mathrm{NC}(60 \% \\
\mathrm{RDN})+\mathbf{4 0 \%} \mathrm{RDF}+\mathrm{Azo}+\mathrm{PSB}\end{array}$ & 74.00 & 77.90 & 75.95 & 76.43 & 76.61 & 76.52 & 70.00 & 70.18 & 70.09 \\
\hline $\begin{array}{l}T_{8} \mathrm{NC}(40 \% \\
\text { RDN)+60RDF+Azo+PSB }\end{array}$ & 73.92 & 78.62 & 76.27 & 77.59 & 77.79 & 77.69 & 71.80 & 71.99 & 71.89 \\
\hline $\begin{array}{l}\mathrm{T}_{9} \text { FYM(30\% RDN)+VC(30\% } \\
\text { RDN)+40\% RDF+Azo+PSB }\end{array}$ & 78.19 & 81.53 & 79.86 & 81.12 & 81.32 & 81.22 & 75.27 & 75.43 & 75.35 \\
\hline $\begin{array}{l}T_{10} \text { FYM( }(20 \% \text { RDN })+V C(20 \% \\
\text { RDN })+60 \% \text { RDF+Azo+PSB }\end{array}$ & 75.36 & 79.06 & 77.21 & 78.28 & 78.44 & 78.36 & 72.52 & 72.73 & 72.62 \\
\hline $\begin{array}{l}T_{11} \operatorname{VC}(30 \% \text { RDN })+\mathrm{NC}(30 \% \\
\text { RDN)+40\%RDF+Azo+PSB }\end{array}$ & 84.20 & 84.63 & 84.41 & 82.43 & 82.60 & 82.51 & 78.61 & 78.76 & 78.68 \\
\hline $\begin{array}{l}\mathrm{T}_{12} \mathrm{VC}(20 \% \mathrm{RDN})+\mathrm{NC}(20 \% \\
\mathrm{RDN})+60 \% \mathrm{RDF}+\mathrm{Azo}+\mathrm{PSB}\end{array}$ & 85.03 & 85.60 & 85.31 & 85.49 & 85.67 & 85.58 & 81.47 & 81.61 & 81.54 \\
\hline $\begin{array}{l}\mathrm{T}_{13} \\
\text { FYM }(20 \% \mathrm{RDN})+\mathrm{VC}(20 \% \mathrm{RDN})+\mathrm{NC} \\
(20 \% \mathrm{RDN})+40 \% \mathrm{RDF}+\mathrm{Azo}+\mathrm{PSB}\end{array}$ & 84.82 & 86.72 & 85.77 & 85.88 & 86.07 & 85.97 & 81.80 & 81.98 & 81.89 \\
\hline $\mathrm{SE}(\mathrm{m}) \pm$ & 3.18 & 3.66 & 2.42 & 2.48 & 3.45 & 2.12 & 2.66 & 2.38 & 1.79 \\
\hline CD at $5 \%$ & 9.27 & 10.69 & 3.20 & 7.23 & 10.06 & 6.03 & 7.77 & 6.96 & 5.08 \\
\hline
\end{tabular}


Table.2 Effect of integrated nutrient management on flowering parameters of gaillardia

\begin{tabular}{|c|c|c|c|c|c|c|c|c|c|}
\hline \multirow[t]{2}{*}{ Treatments } & \multicolumn{3}{|c|}{$\begin{array}{l}\text { Days to first flower bud } \\
\text { initiation }\end{array}$} & \multicolumn{3}{|c|}{ Days to opening of first flower } & \multicolumn{3}{|c|}{ Days to $50 \%$ flowering } \\
\hline & 2018-19 & 2019-20 & Pooled & 2018-19 & 2019-20 & Pooled & 2018-19 & 2019-20 & Pooled \\
\hline$T_{1} \operatorname{RDF}(142: 89: 130)$ & 56.98 & 55.00 & 55.99 & 70.90 & 68.84 & 69.87 & 88.76 & 83.33 & 86.05 \\
\hline $\begin{array}{l}\mathrm{T}_{2} \mathrm{FYM}(20 \% \mathrm{RDN})+\mathrm{VC}(25 \% \mathrm{RDN})+\mathrm{NC} \\
(25 \% \mathrm{RDN})+\mathrm{Azo}+\mathrm{PSB}\end{array}$ & 77.33 & 75.59 & 76.46 & 92.53 & 92.09 & 92.31 & 120.29 & 113.99 & 117.14 \\
\hline $\mathrm{T}_{3} \operatorname{FYM}(60 \% \mathrm{RDN})+40 \% \mathrm{RDF}+\mathrm{Azo}+\mathrm{PSB}$ & 74.05 & 72.59 & 73.32 & 90.17 & 91.35 & 90.76 & 116.46 & 108.58 & 112.52 \\
\hline $\mathrm{T}_{4} \mathrm{FYM}(40 \% \mathrm{RDN})+60 \% \mathrm{RDF}+\mathrm{Azo}+\mathrm{PSB}$ & 76.25 & 75.14 & 75.70 & 88.94 & 88.95 & 88.95 & 120.03 & 112.81 & 116.42 \\
\hline $\mathrm{T}_{5} \mathrm{VC}(60 \% \mathrm{RDN})+40 \% \mathrm{RDF}+\mathrm{Azo}+\mathrm{PSB}$ & 69.28 & 67.08 & 68.18 & 83.06 & 83.05 & 83.06 & 111.46 & 104.00 & 107.73 \\
\hline $\mathrm{T}_{6} \mathrm{VC}(40 \% \mathrm{RDN})+60 \% \mathrm{RDF}+\mathrm{Azo}+\mathrm{PSB}$ & 64.24 & 62.15 & 63.20 & 77.56 & 77.66 & 77.61 & 102.00 & 95.38 & 98.69 \\
\hline $\mathrm{T}_{7} \mathrm{NC}(60 \% \mathrm{RDN})+40 \% \mathrm{RDF}+\mathrm{Azo}+\mathrm{PSB}$ & 60.88 & 58.66 & 59.77 & 76.43 & 73.58 & 75.01 & 98.83 & 88.68 & 93.76 \\
\hline $\mathrm{T}_{8} \mathrm{NC}(40 \% \mathrm{RDN})+60 \mathrm{RDF}+\mathrm{Azo}+\mathrm{PSB}$ & 61.96 & 59.02 & 60.49 & 74.07 & 72.84 & 73.46 & 99.00 & 90.76 & 94.88 \\
\hline $\begin{array}{l}\mathrm{T}_{9} \text { FYM }(30 \% \text { RDN })+\mathrm{VC}(30 \% \\
\text { RDN })+40 \% \text { RDF+Azo+PSB }\end{array}$ & 60.12 & 57.47 & 58.80 & 74.13 & 71.48 & 72.81 & 94.38 & 88.00 & 91.19 \\
\hline $\begin{array}{l}\text { T }_{10} \text { FYM }(20 \% \mathrm{RDN})+\mathrm{VC}(20 \% \\
\mathrm{RDN})+60 \% \mathrm{RDF}+\mathrm{Azo}+\mathrm{PSB}\end{array}$ & 58.91 & 55.82 & 57.37 & 72.90 & 68.09 & 70.50 & 91.71 & 84.76 & 88.24 \\
\hline $\begin{array}{l}\mathrm{T}_{11} \mathrm{VC}(30 \% \mathrm{RDN})+\mathrm{NC}(30 \% \\
\mathrm{RDN})+\mathbf{4 0} \% \mathrm{RDF}+\mathrm{Azo}+\mathrm{PSB}\end{array}$ & 52.12 & 49.58 & 50.85 & 65.02 & 63.93 & 64.48 & 83.76 & 78.84 & 81.30 \\
\hline $\begin{array}{l}\mathrm{T}_{12} \mathrm{VC}(20 \% \mathrm{RDN})+\mathrm{NC}(20 \% \\
\mathrm{RDN})+60 \% \mathrm{RDF}+\mathrm{Azo}+\mathrm{PSB}\end{array}$ & 49.19 & 47.86 & 48.53 & 62.65 & 60.33 & 61.49 & 82.41 & 75.76 & 79.09 \\
\hline $\begin{array}{l}\mathrm{T}_{13} \\
\text { FYM }(20 \% \mathrm{RDN})+\mathrm{VC}(20 \% \mathrm{RDN})+\mathrm{NC}(20 \% \\
\text { RDN })+40 \% \text { RDF + Azo +PSB }\end{array}$ & 44.15 & 42.93 & 43.54 & 56.16 & 54.94 & 55.55 & 72.05 & 67.05 & 69.55 \\
\hline $\mathrm{SE}(\mathrm{m}) \pm$ & 1.63 & 1.36 & 1.06 & 1.59 & 1.64 & 1.14 & 1.96 & 1.92 & 1.37 \\
\hline CD at $5 \%$ & 4.747 & 3.971 & 3.015 & 4.638 & 4.782 & 3.245 & 5.724 & 5.603 & 3.901 \\
\hline
\end{tabular}

Table.3 Effect of integrated nutrient management on quality and yield parameters of gaillardia

\begin{tabular}{|c|c|c|c|c|c|c|c|c|c|}
\hline \multirow[b]{2}{*}{ Treatments } & \multicolumn{3}{|c|}{ Weight of flower(g) } & \multicolumn{3}{|c|}{ Diameter of flower(cm) } & \multicolumn{3}{|c|}{ Flower yield per plant(g) } \\
\hline & 2018-19 & 2019-20 & Pooled & 2018-19 & 2019-20 & Pooled & 2018-19 & 2019-20 & Pooled \\
\hline$T_{1} \operatorname{RDF}(142: 89: 130)$ & 2.49 & 3.10 & 2.79 & 5.83 & 6.28 & 6.06 & 298.29 & 300.99 & 299.64 \\
\hline $\begin{array}{l}\mathrm{T}_{2} \text { FYM }(20 \% \mathrm{RDN})+\mathrm{VC}(25 \% \mathrm{RDN})+\mathrm{NC} \\
(25 \% \mathrm{RDN})+\mathrm{Azo}+\mathrm{PSB}\end{array}$ & 2.20 & 2.43 & 2.31 & 4.91 & 5.59 & 5.25 & 180.58 & 194.73 & 187.66 \\
\hline $\mathrm{T}_{3} \mathrm{FYM}(60 \% \mathrm{RDN})+40 \% \mathrm{RDF}+\mathrm{Azo}+\mathrm{PSB}$ & 2.91 & 2.64 & 2.77 & 5.04 & 5.73 & 5.39 & 201.61 & 195.67 & 198.64 \\
\hline $\mathrm{T}_{4} \mathrm{FYM}(40 \% \mathrm{RDN})+60 \% \mathrm{RDF}+\mathrm{Azo}+\mathrm{PSB}$ & 2.22 & 2.7 & 2.48 & 5.02 & 5.71 & 5.37 & 209.30 & 201.38 & 205.34 \\
\hline $\mathrm{T}_{5} \mathrm{VC}(60 \% \mathrm{RDN})+40 \% \mathrm{RDF}+\mathrm{Azo}+\mathrm{PSB}$ & 2.03 & 2.26 & 2.14 & 5.06 & 5.77 & 5.42 & 229.81 & 226.08 & 227.95 \\
\hline $\mathrm{T}_{6} \mathrm{VC}(40 \% \mathrm{RDN})+60 \% \mathrm{RDF}+\mathrm{Azo}+\mathrm{PSB}$ & 2.33 & 2.56 & 2.44 & 5.38 & 5.85 & 5.62 & 226.58 & 217.89 & 222.24 \\
\hline $\mathrm{T}_{7} \mathrm{NC}(60 \% \mathrm{RDN})+40 \% \mathrm{RDF}+\mathrm{Azo}+\mathrm{PSB}$ & 2.43 & 2.66 & 2.54 & 5.57 & 6.03 & 5.80 & 236.16 & 230.52 & 233.34 \\
\hline$T_{8} \mathrm{NC}(40 \% \mathrm{RDN})+60 \mathrm{RDF}+\mathrm{Azo}+\mathrm{PSB}$ & 2.53 & 2.37 & 2.45 & 5.68 & 6.15 & 5.92 & 246.22 & 238.35 & 242.29 \\
\hline $\begin{array}{l}\mathrm{T}_{9} \text { FYM(30\% RDN)+VC(30\% } \\
\text { RDN)+40\% RDF+Azo+PSB }\end{array}$ & 2.84 & 2.28 & 2.56 & 5.76 & 6.25 & 6.01 & 254.72 & 278.96 & 266.84 \\
\hline $\begin{array}{l}T_{10} \text { FYM(20\%RDN)+VC(20\% } \\
\text { RDN)+60\%RDF+Azo+PSB }\end{array}$ & 2.77 & 2.98 & 2.87 & 5.78 & 6.27 & 6.03 & 289.16 & 286.90 & 288.03 \\
\hline $\begin{array}{l}\mathrm{T}_{11} \mathrm{VC}(30 \% \mathrm{RDN})+\mathrm{NC}(30 \% \\
\mathrm{RDN})+40 \% \mathrm{RDF}+\mathrm{Azo}+\mathrm{PSB}\end{array}$ & 3.20 & 3.60 & 3.40 & 6.05 & 6.44 & 6.25 & 310.71 & 308.57 & 309.64 \\
\hline $\begin{array}{l}T_{12} \mathrm{VC}(20 \% \mathrm{RDN})+\mathrm{NC}(20 \% \\
\text { RDN)+60\%RDF+Azo+PSB }\end{array}$ & 3.30 & 3.70 & 3.49 & 5.85 & 6.32 & 6.09 & 303.39 & 305.87 & 304.63 \\
\hline $\begin{array}{l}T_{13} \\
\text { FYM(20\%RDN)+VC(20\%RDN)+NC(20\%R } \\
\text { DN)+40\% RDF + Azo +PSB }\end{array}$ & 3.61 & 3.61 & 3.61 & 6.37 & 6.52 & 6.45 & 386.07 & 408.39 & 397.23 \\
\hline $\mathrm{SE}(\mathrm{m}) \pm$ & 0.129 & 0.127 & 0.091 & 0.20 & 0.22 & 0.13 & 8.84 & 10.47 & 5.93 \\
\hline CD at $5 \%$ & 0.377 & 0.370 & 0.258 & 0.59 & 0.63 & 0.36 & 25.79 & 30.57 & 16.87 \\
\hline
\end{tabular}


The reduction in days to initiation of first flower bud, number of days to opening of flower and number of days to $50 \%$ flowering might be due to the application of huge quantity of vermicompost as it is rich in humic acid which helps in production of auxins and growth substances at an early phase of growth. Easy uptake of different nutrients and simultaneous transportation of growth promoting substances like cytokinin to the auxiliary buds resulted in breakage of apical dominance in plant, thus leads to earliness of bud initiation in bio-fertilizer applied plants. Ultimately, these processes result in better site for mobilization of photosynthates and conversion of vegetative parts of plant to reproductive phase. In addition to this, neem cake not only supplied the NPK but also contained micronutrients and amino acids. Also, the neem cake protects the plants from nematodes. The earliness in flowering might be due to application of nitrogen, phosphorus and potassium from different sources viz., organic manures and inorganic fertilizers which promoted translocation of phytohormones to the shoots and resulted in early flower initiation. Similar findings were cited by Airadevi (1) and Bohra and Kumar (3) in chrysanthemum, Patil et al., (12) in china aster, Kumura et al., (8) and Thumar et al., (17) in African marigold.

The earliness may be also due to the presence of gibberellins in FYM and vermicompost which regulates flowering and causing early flowering through uptake of nutrients. Thus, due to availability of optimum level of all the nutrients plants soon completed their vegetative growth, resulting in early flowering. These findings are in close conformity with the findings of Karetha (6), Deshmukh et al., (5), Rathod et al., (14) and Sowmyamala et al., (16) in gaillardia.

Different nutritional treatments under investigation had significant effect on quality parameters viz., weight of flower (g) and diameter of flower $(\mathrm{cm})$ in gaillardia in both the years i.e. 2018-19 and 2019-20 and in pooled analysis (Table 3). The maximum weight of flower $3.61,3.61$ and $3.61 \mathrm{~g}$ and diameter of flower $6.37,6.52$ and $6.45 \mathrm{~cm}$ was recorded at full bloom stage in both the years as well as in pooled data with the application of treatment of FYM (20\% RDN) + Vermicompost (20\% RDN) + Neemcake $(20 \% \mathrm{RDN})+40 \%$ recommended dose of NPK with Azotobacter and PSB ( $\left.\mathrm{T}_{13}\right)$.

The increase in flower weight and flower diameter with the application of organic fertilizers along with chemical fertilizers could be due to the enhanced photosynthetic activities which, in turn, favored higher accumulation of dry matter and also contributed in efficient partitioning of photosynthates towards the sink (Mohanaty, 9). Level of ammonia also increased by Azotobacter and PSB diverted the photo assimilates in the plant to the developing buds which in turn increased flower weight and flower diameter. These results are closed to the findings of Rathod et al., (14), Sowmyamala et al., (16) and Karetha (6) in gaillardia, Bhat et al., (2), Kumar et al., (7) and Kumura et al., (8) in marigold.

The data presented in the Table 3 revealed that different nutritional treatments had significant effect on yield parameter like flower yield plant ${ }^{-1}(\mathrm{~g})$ in gaillardia in both the years i.e. 2018-19, 2019-20 and in pooled analysis. The maximum flower yield per plant $386.07,408.39$ and $397.23 \mathrm{~g}$ was recorded in both the years and in pooled data, respectively with the application of treatment of FYM $(20 \% \mathrm{RDN})+$ Vermicompost (20\% RDN) + Neemcake $(20 \% \mathrm{RDN})+40 \%$ recommended dose of NPK with Azotobacter and PSB ( $\left.\mathrm{T}_{13}\right)$. The higher flower yield recorded in $\mathrm{T}_{13}$ is due to combined effect of bio-fertilizers along with $40 \%$ RDF, neem cake, FYM and 
vermicompost. Palagani et al., (10) found similar results in chrysanthemum.

These organic and inorganic fertilizers produced growth promoting substances such as IAA, GA, vitamin $\mathrm{B}_{12}$, thiamine, riboflavin etc. which in turn enhanced the soil fertility resulting in better shoot and root development and thereby plant growth. Also, these fertilizers affect the reproductive cycle of plant and initiate profuse flowering resulted in increase in flower yield plant $^{-1}$. Parallel results have also been reported by Rathod et al., (14) and Sowmyamala et al., (16) in gaillardia, Thumar et al., (17) and Singh et al., (15) and Kumura et al., (8) in marigold.

From the study it can be concluded that Treatment $\mathrm{T}_{13}, \quad$ FYM $(20 \% \quad \mathrm{RDN})+$ Vermicompost (20\% RDN) + Neemcake $(20 \% \mathrm{RDN})+40 \%$ recommended dose of NPK with Azotobacter and PSB enhanced the growth, flowering flower quality and yield attributes in gaillardia. Replacement of inorganic fertilizers with various organic sources in gaillardia is an important aspect for the commercial production of gaillardia It is only possible by the combined use of inorganic, organic and bio-fertilizers. It is therefore important to make the judicious use of these natural resources for sustainable farming and better health of soil.

\section{References}

Airadevi, P.A. 2012. Integrated nutrient management studies in garland chrysanthemum. Bioinfolet. 9: 430-434.

Bhat, D.J., Dogra, S., Pandey, R.K., Sharma, J.P. and Jamwal, S. 2010. Influence of integrated nutrient management on growth, flowering and yield of African marigold cv. Pusa narangi gainda. Environment \& Ecology.25: 466-468.

Bohra, M. and Kumar, A. 2014. Studies on effect of organic manures and bio- inoculants on vegetative and floral attributes of chrysanthemum cv. Little darling. The Bioscan.9:1007-1010.

Carig, R.M. 1977. Proceeding Florida State Horticultural Society, 90: 108-110.

Deshmukh, G., Khlralkar, P., Bagde, S.D. and Bhongle, S.A. 2008. Effect of bioinoculants with graded doses of NPK on growth and yield of gaillardia. Journal of Soils and Crops. 15: 212-216.

Karetha, K.M., Jat, G., Singh, V. and Gajipara, N.N. 2011. Effect of different levels of NPK on growth, yield and yield attributes of gaillardia (Gaillardia pulchella) cv. Local Double. Asian Journal of Horticulture. 6:344-347.

Kumar, S., Singh, J.P., Mohan, B., Nathiram and Rajbeer. 2013. Influence of integrated nutrient management on growth, flowering and yield parameters of marigold (Tagetes erecta L) cv. Pusa Basanti Gainda. Asian Journal of Horticulture. 8: 118-121.

Kumura, A., Pandey, G., Mishra, P.P. and Kumar, R.2019. Effect of Integrated Nutrient Management on Growth and Flowering of African marigold (Tagetes erecta) cv. Pusa Narangi Gainda. International Journal of Current Microbiology and Applied Sciences 8: 1271-1278.

Mohanaty, A. Srichandan, S. and Behera, P. 2018. Effect of integrated nutrient management on nutrient uptake in marigold in different seasons. The Pharma Innovation Journal. 7: 13-16.

Palagani, N., Barad,A.V. and Bhosale, N. 2015. Response of chrysanthemum (Chrysanthemum morifoliumR.)cv. IIHR-6 to integrated nutrient management. Bioinfolet. 12: 79-84.

Patanwar, M., Sharma, G., Banjare, C., Chandravanshi, D. and Sahu, E. 2014. Growth and development of chrysanthemum (Denndranthema grandiflora Tzelev) as influenced by 
integrated nutrient. Indian Journal of Ecology.36: 93-94.

Patil, R.S., Hanumanthappa, M.J., Hagde, N., Maheshwar,K.J. and Nagesha, L. 2013. Effect of integrated nutrient management on growth, yield and vase life of china aster (Callistephus chinensisL. Nees) for coastal Karnataka. Environment \& Ecology. 31: 11041106.

Patil, V.S. and Agasimani, A.D. 2013. Effect of integrated nutrient management on growth and yield parameters in china aster (Callistephus chinensis). Mysore Journal of Agricultural Sciences.47: 267-272.

Rathod, N.G., Narwadkar, P.R., Sajindranath, A.K. and Prabu, T. (2002). Effect of integrated nutrient management on growth and yield of gaillardia. Journal of Maharashtra Agricultural University.27:318-319.

Singh, P.S., Prakash, M., Kumar, S., Singh,
M.K. and Kumar, A.2015. Effect of integrated nutrient management on growth flowering and yield in marigold (Tagetes erecta L). Annalas of Horticulture. 8: 73-80.

Sowmyamala, B.V and Nagaraju H.T. 2012. Effect of organic and inorganic fertilizers on growth and yield of gaillardia (Gaillardia pulchella cv. DGS-1). An Asian Journal of Soil Sciences.8: 53-55.

Thumar, B.V., Barad, A.V. Neelma, P. and Bhosale, N.2013. Effect of integrated system of plant nutrition management on growth, yield and flower quality of African marigold (Tagetes erecta L) cv. Pusa Narangi Gainda. Asian Journal of Horticulture. 8:466-469.

Tija B, Rose S.A. 1988. Salt tolerant bedding plants. Proceedings of florida state horticultural society. 100:181-182.

\section{How to cite this article:}

Arti Arha, R. A. Kaushik, S. S. Lakhawat, H. L.Bairwa and Arvind Verma. 2021. Effect of Integrated Nutrient Management on Growth, Flowering and Yield of Gaillardia. Int.J.Curr.Microbiol.App.Sci. 10(01): 3461-3468. doi: https://doi.org/10.20546/ijcmas.2021.1001.408 